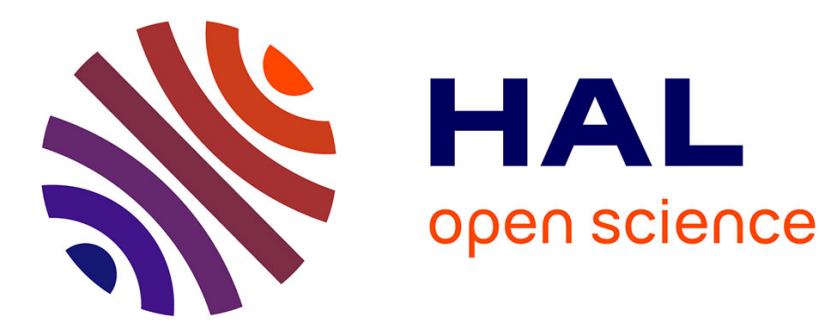

\title{
Psychoanalysis and evaluation: a stratified model focused on the uniqueness of the case
}

Guénaël Visentini, Adrien Blanc, Laurie Laufer

\section{To cite this version:}

Guénaël Visentini, Adrien Blanc, Laurie Laufer. Psychoanalysis and evaluation: a stratified model focused on the uniqueness of the case. The Scandinavian Psychoanalytic Review, 2019, pp.1-14. 10.1080/01062301.2019.1692621. hal-02399544

\section{HAL Id: hal-02399544 \\ https://hal.science/hal-02399544}

Submitted on 9 Dec 2019

HAL is a multi-disciplinary open access archive for the deposit and dissemination of scientific research documents, whether they are published or not. The documents may come from teaching and research institutions in France or abroad, or from public or private research centers.
L'archive ouverte pluridisciplinaire HAL, est destinée au dépôt et à la diffusion de documents scientifiques de niveau recherche, publiés ou non, émanant des établissements d'enseignement et de recherche français ou étrangers, des laboratoires publics ou privés. 


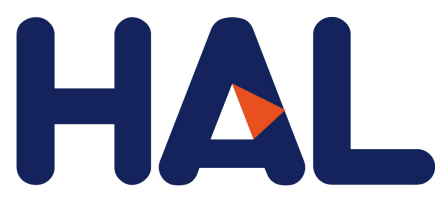

archives-ouvertes

\title{
Psychoanalysis and evaluation: a stratified model focused on the uniqueness of the case
}

\author{
Guénaël Visentini, Adrien Blanc, Laurie Laufer
}

\section{To cite this version:}

Guénaël Visentini, Adrien Blanc, Laurie Laufer. Psychoanalysis and evaluation: a stratified model focused on the uniqueness of the case. The Scandinavian Psychoanalytic Review, 2019, pp.1-14. 10.1080/01062301.2019.1692621. hal-02399544

\section{HAL Id: hal-02399544 \\ https://hal.archives-ouvertes.fr/hal-02399544}

Submitted on 9 Dec 2019

HAL is a multi-disciplinary open access archive for the deposit and dissemination of scientific research documents, whether they are published or not. The documents may come from teaching and research institutions in France or abroad, or from public or private research centers.
L'archive ouverte pluridisciplinaire HAL, est destinée au dépôt et à la diffusion de documents scientifiques de niveau recherche, publiés ou non, émanant des établissements d'enseignement et de recherche français ou étrangers, des laboratoires publics ou privés. 


\title{
PSYCHOANALYSIS AND EVALUATION: \\ A STRATIFIED MODEL FOCUSED ON THE UNIQUENESS OF \\ THE CASE
}

Guénaël Visentini, Adrien Blanc \& Laurie Laufer

\begin{abstract}
\end{abstract}

\section{Objectives}

This article addresses the methodological controversies surrounding the issue of how to evaluate the psychotherapies. It proposes to identify the principles of an integrative and stratified model in order to report the results of analytical therapy (its efficacy) based on the very effectiveness of its processes. Thus, the uniqueness of the case is put at the center of the evaluation setting.

\section{Methods}

Drawing on science studies, the authors engage in a reflexive exercise on the problem of psychoanalysis' evaluation based on methodological questions raised in the field over time and current issues related to practice.

\section{Results}

First, the regularly asserted opposition between the norms of analytical practice and those governing standard evaluation procedures is reinterpreted as the effect of a lack of intermediate epistemic patterns.

Second, the fundamental principles of an integrative model are considered so as to translate and articulate a set of heterogeneous requirements into distinct strata.

\section{Discussion}

Since psychoanalysis is fundamentally a case-by-case practice characterized by inequivalence and unexpectedness, its utmost aim is to use a type of effectiveness based on the singularity of the case. However, this does not prevent it from being evaluable provided that the epistemic levels of the evaluation are clearly differentiated.

Keywords: individual case, epistemology, randomized controlled trials, evaluation scales, qualitative 


\title{
PSYCHOANALYSIS AND EVALUATION: \\ A STRATIFIED MODEL FOCUSED ON THE UNIQUENESS OF THE CASE
}

\author{
Size is not automatically objective [...]. Numerical \\ precision $[\ldots]$ is $[\ldots]$ [o]ne of the clearest signs of a non- \\ scientific mind. We must reflect in order to measure and \\ not measure in order to reflect.
}

BACHELARD (1938/2002, pp. 211-213).

\section{INTRODUCTION}

\section{A Controversial Evaluation System}

Since the 1980s, public policy-makers currently draw on research to ensure better health care policies (DeLeon, 1988). In relation to "mental health," their requests have focused on the efficacy of different psychotherapeutic approaches (Klerman, 1983; Newman \& Howard, 1986). However, the evaluation of these practices implies the availability of adequate measurement tools (Strupp, 1986). As a result, a dedicated research field has progressively emerged, focusing on the discussion of evaluation methods even before considering the results they provide.

Nowadays, while the objective of "good governance" in psychological care has reached a broad consensus, the means implemented in order to achieve this end are still widely debated (Norcross, Beutler \& Levant, 2005). In response to the scientific accuracy of protocols used in experimental sciences, clinicians stress that in situ evaluation of therapeutic methods involves circumstantiated truth. In response to the sort of data produced by clinical experience, experimental scientists highlight the lack of standardization and quantification, without which different clinical approaches cannot be compared (Garfield, 1992).

Hence, evaluating the efficacy of different therapies raises a series of questions. The choice of methodology implicitly calls on the ethical, political, and scientific positions of researchers, which lead to decisions that must be weighed (Visentini, 2017). Indeed, these 
bring to the fore or, on the contrary, render invisible certain aspects of the psychotherapy experience. They define what is significant and what is inconsequential in treatment. In this respect, let us cite the contentious issues linked to the definition of evaluation items, the conventions used for protocols, the choice of reference diagnostic models and the means to construct them, the agreement on patient selection processes, and the consensus on consent criteria for research studies (Champion, 2008).

The science studies, of which the pioneering research in the 1970s and 1980s nowadays constitutes the reference for the pragmatic approach to science (Pestre, 2010), demonstrates how in the practices of researchers, beyond the predominant positivist ideal of the nineteenth century, different perspectives of truth confront one another: the tools of science - methods, proofs, and demonstrations - should not only be viewed as (stable and evident) references in the debate, but also as objects of the same controversial debate. The same applies to the evaluation methods of the psychotherapies, even if this dimension is sometimes too easily overlooked.

\section{For a Model Centered on the Case's Uniqueness in Psychoanalysis}

Here, we do not intend to delve into the exhaustive historical cartography of the controversies associated with the psychotherapies' evaluation. Nor is it our goal to systematically review all the studies that propose new evaluation methods more suited to analytical practice (e.g., Crits-Cristoph \& Barber, 2000; Leuzinger-Bohleber \& Target 2002; Kächele, Levy \& Ablon, 2012; Kazdin, 2014). What we instead seek to sketch out in this article is more limited and takes a different approach. Based on our concrete interventions as psychoanalytically oriented psychologists, we would like to problematize anew the issue of the specific evaluation of the psychoanalytic therapies by reasserting the true significance of the uniqueness of each patient's case.

Two perspectives currently dominate methodological discussions around the evaluation of psychoanalysis - in both France and English-speaking countries (Leuzinger-Bohleber, Kächele, et al., 2015) - but they paralyze ideas into a sort of "immobile debate" (Doury, 1997). First, for some "purist" psychoanalysts (generally in private practice), there is a refusal to enter the "arena" of discussions on evaluation methods and demands for an extraterritorial position relative to these issues and institutional requirements. Second, for those affiliated with public institutions (namely clinicians and lecturers), the attempts to evaluate the effects of analytical practice, despite their fruitfulness and interest, appear to circumvent the founding 
ethos of psychoanalysis: that of a structured encounter with a patient, whose therapeutic efficacy - such is its reasoned gamble - derives from an availability that, within the limits of the formal structure, makes each case unique.

On the one hand, the massive rejection of evaluation methods as "irrelevant" to psychoanalysis seems to harm this very practice, which is partially constructed around medium-term expectations and continual reflexive adjustments of the work. On the other hand, one is confronted with evaluation methods that preclude or, in the best of cases, restrict the consideration of unforeseen outcomes among both psychoanalysts and patients, contingencies that lie at the very heart of analytical practice and its effects. Such protocols therefore do not evaluate the specificity of psychoanalytic work and bring us to discuss the analytical relevance of the evaluation.

Neither path would seem to encompass all methodological possibilities. Since Freud, however, a third trend has existed at the height of practices, giving great importance to "unique operative representations," but it has only rarely been formalized. We would like to reflect on its content and integrate it into the evaluation process. Our perspective is thus highly pragmatic. We will not dismiss one aspect of the clinical situation in favor of others but instead strive to link the different categories of experience in a stratified overview. It is thus conceivable to bring together the unique, typical, and quantifiable aspects of psychoanalytic practice, provided that these different evaluative phases are articulated without being confounded, that is, by treating them as a succession of heterogeneous translations of the same experience, without reducing this evaluative chain to its final translations (statistical results, tools to support institutional decision-making) or intermediate ones (measures of change).

\section{Outline of a Critical Proposal}

This article is comprised of three parts. First, we focus on the political and epistemological controversies concerning the evaluation of psychoanalysis. Second, we critically synthesize the contributions and limitations of the existing evaluative models. Third, we propose the principles of an integrative and stratified model, centered on the uniqueness of the case, with the intention to shed new light on the issue.

It would thus seem feasible - by staging the evaluative process - to respond to the legitimacy of scientific requirements and public demands (quantified and comparative approaches, or according to our lexis, "chains of tertiary evaluations"), without losing sight of 
effective clinical practice (approach based on typical and qualitative cases, or "chains of secondary evaluations") or the analyticity of clinical practice (approach based on the uniqueness of each case, or "chains of primary evaluation"), all the while not compromising the chief concern of the evaluation system in the interest of this patient and not for any other.

\section{POLITICAL-EPISTEMOLOGICAL CONTROVERSIES AROUND THE ISSUE OF EVALUATION}

First, it is necessary to grasp the ambiguity of the relationship between psychoanalysis and evaluation. While analytical practice implies the permanent evaluation of the processes and outcomes of analysis, the vast majority of psychoanalysts have historically opposed the very idea of evaluating their own practices.

Despite the various reasons asserted for refusing a "scientific" evaluation of practices, another position can be more valuably supported on political and ethical grounds. This alternative position, increasingly accepted nowadays, involves a renewed criticism of the epistemic limits of the current methods but in a constructive and integrative approach. For whom are we evaluating and for what reasons? Is it simply to subscribe to the management imperatives of the healthcare system, which is always likely to believe in the truth of a single scientific method to simplify its administration of problems? Or should the clinical relevance of the approach equally be taken into account? Unless these questions are asked, the notion of evaluation in all its conceptual ambiguity remains epistemically problematic.

\section{Contexts of the Evaluative Ideal}

In a research approach, the question of evaluation in psychoanalysis emerged very early (Coriat, 1917) and has never stopped being asked. ${ }^{1}$ It is undeniable, however, that it has taken another turn with the rise of "new public management" since the 1980s - first in the AngloSaxon world and then at the European level. By adopting private-sector criteria, this new way of managing public institutions consists of allocating budgets in accordance with performance indicators (Lascoumes \& Le Galès, 2004). For any public investment, an independent control

\footnotetext{
${ }^{1}$ Since 1999, the Research Committee of the International Psychoanalytical Association has regularly updated an excellent summary of the scientific research relating to the evaluation of psychoanalysis as well as epistemological and methodological issues (Leuzinger-Bohleber, Kächele, et al., 2015).
} 
of efficacy is required, even when this sometimes clashes with the practical standards of the concerned persons (Boltanski \& Chiapello, 1999). Health historians and sociologists have since shown that this governance by numbers entails the normalization (artificial classification, numeral reduction) and control (obsession with performance by means of projects and assessments) of public health practices (Benamouzig 2005; Tournay et al., 2007).

The stated purpose, imbued with democratic ideals and economic rationality, and respectful of the shared ethics of care, is to provide citizen-consumers with the most efficient services that deliver the best value for money. However, many studies have shown that the effects on institutional psychotherapy work are sometimes opposed to the desired goals: it often results in a reduction in clinical freedom, a routinization of practices, the oppressive control of the hierarchy, the time lost in reporting on one's work instead of working, the demobilization of stakeholders, and lastly, a decline in efficacy and weakening of health care services. Indeed, the management needs of public health policies sometimes end up prevailing over the objective of improving health care (Berg \& Timmermans 2003; Haliday \& Naudin, 2019).

Concerning the very specific field of the psychotherapies, the whole problem has revolved around the classification of their efficacy: how to identify and sort disorders, how to define proposed treatments, and how to control their implementation? From the 1970s and 1980s, the chosen methods were initially randomized controlled trials (Haaga \& Stiles, 2000). These evaluation protocols were (and still are) based on the gold standard of "evidence-based medicine", itself derived from the methodological norms that had proven their success in the experimental sciences: the standardized definition of experimental situations, testable hypotheses, reproducibility, and a high degree of objectivity in the results with the desubjectivization of experiments and ultra-segmentation of research objects, aiming to isolate "specific" determinant factors (Marks, 1999).

The application of this gold standard to the domain of the psychotherapies, baptized as empirically supported psychotherapy (ESP) and at the time advocated and supported by the American Psychiatric Association (APA), led to testing the psychotherapies in the same way as chemical molecules are tested, notably for their supposed internal efficacy alone and independently of the circumstances (therapist quality, patient's psychological organization, treatment context, and therapy timeframe). Such a choice did not encourage the involvement of analysts in these research projects. In the Anglo-Saxon world, however, the historical links between psychoanalysis and medicine, not to mention the more pragmatic state of mind, 
encouraged some analysts to integrate experimental evaluation systems. In the rest of Europe, however, the position was more critical. In France (from where we write), the refusal was massive based on the grounds that no external statistical evaluation could enrich the practice on a case-by-case basis.

Our general position is as follows:

- either we should accept that psychoanalysis excludes itself from health institutions (and confines itself to private practice) by refusing to account for its practice, which in our view is not particularly responsible (with regard to both patients and the history of the discipline);

- or we should oppose this situation: and such a decision cannot be limited to a mere position of principle, but must rather compel professionals to enter the debate. And not only to condemn but also to explain in the double sense of explaining to oneself (reflecting on practices) and explaining to scientists and politicians (expounding the specificity, objectives, and means of clinical practice, and situating its contributions and limitations).

Hence, the necessary return to an "analytical epistemology of psychoanalysis" (Visentini, 2015) founded on practices. How does psychoanalysis work, what can be expected of it for each individual patient (before learning about its statistical promises), how should it be evaluated, and how can it be positioned among other approaches? The aim here is to influence the current debates in order to liberate new evaluation levers.

\section{Does Evaluation Exist in Psychoanalytic Practice?}

Psychoanalysis derives from the medical domain, even though Freud and the entire tradition of analysts to this day consider it to be a non-medical branch - an apparent paradox. Its therapeutic aim (like medicine) is to contribute to a greater sense of somatopsychological well-being, but (in a non-medical way) using only speech-based treatment.

For this purpose, psychoanalysis - through speech and its effects - seeks to subtly make sense of what occurs in a session in order to proceed in the most optimal way. In this manner, it involves continuous evaluations, whose principal characteristics are the qualitativeness and consideration of patients' self-evaluations.

\section{Evaluating is not only Quantifying: The Semio-Typological Paradigm}

To free up space for the thinkable, it is important to unravel the all-too obvious evaluation/quantification pair by hardening their ideological power relations that have given 
primacy to the quantitative and statistical ideal. Indeed, other effective types of nonquantitative evaluation have and still are being practiced.

In 1979, Ginzburg proposed grouping these types of non-quantitative evaluation under the name of "semiological paradigm." This means "thinking and evaluating by signs" prior to the application of any other measure: the knowing subject extracts the distinct qualitative traits of the experience and then reflects on them, leading to the elaboration of series, comparisons, and typologies (with an increase in generalization) wherein practical rigor excels in relation to the desired aim.

This idea - let us call it "semio-typological" to stress the cognitive continuum between the signs and the types - is likely to vary greatly depending on the field to which it applies (i.e., legal, medical, moral, political). In analytical practice, a diversity of semiological attention and typological reasoning of an evaluative order is at work in every session.

Let us give but a few non-exhaustive examples:

- in relation to adults: sensorimotor dynamics, vocal modulations, types of gaze, kinds of transference demand, level of anguish, modes of psychological defense, potential of free association, and organization of dreams;

- in relation to children: types of verbal and gestural interactions between parents and children, means of entering into contact with food, features of drawings (representation of the body, self, and family members, usage of color, composition of shapes), and games (sensoriality, narrativity, fantasmatization);

- in relation to analysts themselves: counter-transference feelings of anguish, boredom, traps, void, anger, identification, and so on in response to the transference demands of patients.

All these signs, extracted from experience, correspond to a semiology (enriched with respect to the traditional semiology of medicine and psychiatry), which can be qualified as "psychoanalytical," as the therapist situates it in the context of transference. In addition to the directly observable signs are the signs relating to the speech acts, dreams, and games addressed to the therapist, as well as the signs relating to the analyst's thoughts in his own psychological reality, which he can reflect on with another analyst (reflexive supervisory framework).

By broadening our attention to these signs and their evolution over time, many internal evaluations of the clinical situation take place, which are required by the analytically oriented practitioner in order to objectify the dynamics at work and guide his interventions. 


\section{The Consideration of Patients' Self-Evaluations: An Analytical Specificity}

Beyond these standard evaluations, what is specific to the psychoanalytical approach is the significance accorded to the unique elements that emerge in the evaluative process. Indeed, the therapeutic challenge of psychoanalysis resides in the time and freedom accorded to the patient in his ad hoc interactions in order to explore his inherent psychological organization - his own representations. This allows him to address them to the therapist (transference) and receive knowledge in return, metabolized through the analyst's external perspective. This reflexive feedback entails analysis in the patient's psychical apparatus - a momentary disorganization of his psychological life -, which permits new syntheses. The patient, hence becoming an analysand, psychologically reorganizes himself in a different manner, with possible therapeutic effects.

Psychoanalysis is not simply external evaluative knowledge that is applied to a given type of patient (or case, in the generic sense of the term). It is above all a practice that allows the primary evaluations of a patient to intervene in joint therapeutic work. Depending on the significance of certain representations for the patient, analytical therapy may take a unique turn. And the uniqueness of the material delivered by the patient constitutes the very therapeutic resource.

For this reason, Lacan warned against overestimating diagnosis:

I would like to make one point, namely that subjects of a particular type, whether hysterical or obsessional according to the old clinical classification, are unconcerned by individuals of the same type (Lacan, 1975, p. 79).

In other words, two patients of a similar "type," at the very heart of their subjective functioning, their unconscious fantasmatization, the quality of their anguish, the content of their ideals and their relation to them, and the themes and forms of their most significant dreams, have absolutely nothing in common with each other, even if, at a higher level of abstraction, they may be classified in the same category.

This is likewise the path followed by Freud after establishing his approach. The analytical treasure that becomes enriched with each generation of analysts, this pooling of operational psychological representations (allowing effectiveness to be measured), can only be considered in reference to individual patients: Lucy $\mathrm{R}$ and the cigar smell, which manifested as a sign of trauma and then disappeared during treatment (Freud, 1895); Ernst 
Lanzer's phantasmatic relation to the verbal bridge "Ratten," whose psychological disinvestment by the analysand signifies the end of neurosis (Freud 1909b); the overdetermined relation of Little Hans to heavily laden horses, which, once understood by the child as a parental complex, allowed his phobia to unfold (Freud, 1909a).

These representations, which stand as signs of uniqueness, juxtapose the typical clinical signs, while retaining a greater therapeutic significance. It is in and by the extraction of these unique case features (elements that constitute their own category) that the work and its effects may progress. They allow what is important to the patient to be worked on, and not something else. They make it possible to evaluate what is at stake, as well as any movements, advances, and changes. They thus lie at the heart of the practical evaluation of psychoanalysis. At the level of typical features, evaluation serves to orientate the work, but these unique traits considered in their context have to be brought hic et nunc into play. And this can only occur because the very framework prohibits any type of protocolization.

This raises the question of the operative epistemological register: as psychoanalysts, at which levels of focus and intervention do we act in order to obtain the optimal therapeutic outcome? If it is understood to be at the level of what the case in the fullest sense of the word contributes, at the level of the patient's self-evaluations as reflected by the analyst in therapy, at the level of the patient's own knowledge (not a priori known by the analyst), then we can gain new insight into the clinical and epistemological limitations of the methods implemented to date for evaluating psychanalysis.

\section{CONTRIBUTIONS AND LIMITATIONS OF THE CURRENTLY DOMINANT MODELS}

The difficulty in evaluating the efficacy of the psychotherapies dates back to early practices. Throughout the $20^{\text {th }}$ century, both during and after Freud's time, various evaluation procedures were put in place with increasingly rigorous epistemic controls. Wallerstein proposed to organize them into four methodological generations that encroach on each other chronologically (Wallerstein, 2001):

- the first (1917-1968) consists of simple retrospective counts of successes, without a rigorous definition of criteria;

- the second (1959-1985) proposes single and serial case studies based on more specific criteria; 
- the third (1954-1986) adds follow-up evaluations to the second and implements separate evaluations for both the treating and follow-up analysts;

- the fourth (since 1970) uses technological progress (audio and video recordings) to provide even greater control over the reliability, processing, and interpretation of data.

These four generations of research completed under naturalistic conditions with questionnaires, follow-up interviews, and rating of change by external peers have led to the conclusion that psychoanalysis has a definite therapeutic effect (Schjelderup, 1955, 1956; Pfeffer, 1959, 1961, 1963; Schlessinger \& Robbins, 1974; Oremland, Blacker \& Norman, 1975; Wallerstein, 1968, 1986; Kantrowitz, Katz \& Paolitto, 1990a, 1990a, 1990b, 1990c), while testing a few hypotheses about the different factors of change such as transference engagement, the patient's psychological capacities, or the analyst's own investment.

However, the 1970s and 1980s marked a methodological turning point. Randomized controlled trials (RCTs), which became the gold standard of evidence-based medicine, were gradually imported and transposed into the field of psychotherapy, thus making previous research obsolete in the eyes of scientists and public policy-makers. The ambition was to desubjectify and de-contextualize the evaluation processes (by methodologically excluding nonspecific factors) in order to compare the supposed active factors, namely, therapy type with therapy type.

\section{Achievements and criticisms of randomized controlled trials}

Though initially reluctant, psychoanalysts adopted these standard methodologies - with France being an exception, along with a few other countries. What did they contribute? An international consensus first recognized that all psychotherapies, regardless of their nature, have a mean clinical effect superior to placebo and drugs (Luborsky, Singer \& Luborsky, 1975; Smith, Glass, \& Miller, 1980). They are therefore not the result of mere suggestion. A large wave of RCTs sought to determine whether one type of therapy would be superior to others. But the meta-analyses did not meet expectations.

No statistically significant differences were found for all disorders combined (Steinert, Munder, Rabung, Hoyer \& Leichsenring, 2017; Fonagy, 2015; Kivlighan, Goldberg, Abbas, Pace, Yulish \& Wampold, 2015; Wampold, Minami, Baskin \& Callen Tierney, 2002) or according to type of disorder such as various somatic disorders (Abbass, Kisely, \& Kroenke, 2009), mental disorders (Leichsenring, Leweke, Klein \& Steinert, 2015), complex mental 
disorders (Leichsenring \& Rabung, 2011), depression (Leuzinger-Bohleber et al., 2019b), post-traumatic stress disorder (Benish, Imel \& Wampold, 2008), anxiety disorders (Keefe, McCarthy, Dinger, Zilcha-Mano, \& Barber, 2014), personality disorders (Leichsenring \& Leibing, 2003), alcohol use disorders (Imel, Wampold, Miller, \& Fleming, 2008), and common disorders (Abbass, Hancock, Henderson, \& Kisely, 2006).

Meta-analyses have been unable to isolate any significant differential efficacy between short-term (Town, Diener, Abbass, Leichsenring, Driessen \& Rabung, 2012) and long-term therapies (De Maat, De Jonghe, Schoevers \& Dekker, 2009).

While RCTs and meta-analyses have not been able to differentiate between the different competing therapies, they at least conclude that the psychotherapies are valid care practices for mental disorders (even for some somatic ones). ${ }^{2}$ Although specific factors cannot distinguish between their efficacies, non-specific factors should be the subject of future research studies to gain better knowledge of the active therapeutic processes (Wampold \& Imel, 2015). But as RCTs have failed to understand why and how the psychotherapies effectively work, their relevance has gradually been criticized. While numerous limitations have already been identified regarding their initial object - medicine - (Seshia \& Young, 2013a; 2013b), it has been noted that these limitations are exacerbated when it comes to testing the effectiveness of the psychotherapies (Zepf, 2008 ; Carey \& Stiles, 2015). RCTs only work well if they can isolate a specific causal factor, "all other things being equal." And it is indeed this major methodological clause that is insufficiently feasible in terms of psychotherapeutic treatment. The very limited differential results of RCTs indicate that it is difficult to neutralize the effects of the following:

- the therapist relative to the progress of the therapy (even if the therapy is manualized);

- the patient's own resources relative to their therapy (even when implementing standard diagnoses, with high inter-rater reliability);

- the meeting relative to the advancement of the therapy (even if the administration and dosage of the therapy are protocolized).

Researchers have gradually recognized that the psychotherapies cannot be considered like drugs in the sense that the effects of the latter are strictly specific and unilateral, that all their internal ingredients can be listed, and that they can be isolated from the therapists administering them. It therefore emerged that RCTs were not the most appropriate method for

\footnotetext{
${ }^{2}$ For example, they are included among the ten validated forms of healthcare in Obamacare (Lazar \& Yeoman, 2014).
} 
evaluating the efficacy of the psychotherapies, even though they are currently the best-known approach in the medical field (Mellor-Clark, Cross, Macdonald \& Skjulsvik, 2014). Applied to the evaluation of the psychotherapies, the gold standard of RCTs is thus increasingly considered to be "evidence b(i)ased medicine" (Melander, Ahlqvist-Rastad, Meijer et al., 2003). From the 1990s, new approaches were developed, including a return to the structured and controlled observation of individual cases, serialized for comparative purposes (Kazdin, 1997, 2001).

\section{Achievements and Limits of Evaluation Methodologies under Naturalistic}

\section{Conditions}

At the turn of the $20^{\text {th }}$ and $21^{\text {st }}$ centuries, an old question from Gordon Paul resurfaced: "What treatment, by whom, is most effective for this individual with that specific problem, and under which set of circumstances?" (Paul, 1967, p. 111). This leads to a rediscovery of pragmatic in situ evaluation settings (Fishman, 1999; Crits-Cristoph \& Barber, 2000; Leuzinger-Bohleber \& Target, 2002). Beyond the "all RCTs," research regains insight from the old psychoanalytical tradition, while imposing new scientific requirements on it. The latter also significantly raised its methodological standards during the 1980s, with, for example, the pioneering work of the Ulm Psychoanalytic Process Research Study Group in Germany (Kächele, 1988) and others (Jones, 1985; Weiss, 1986; Luborsky \& Crits-Christoph, 1990; Dahl \& Teller, 1994; Horwitz \& al, 1996; Bucci, 1997), which were then integrated into the Collaborative Analytic Multi-Site Program (CAMP) led by Wallerstein within the American Psychoanalytic Association (Wallerstein, 1991).

Around the 2000s, the basic idea was as follows: statistical efficacies - in addition to being slightly differentiated - are much less interesting for patients than more contextual efficacies, with respect to a particular type of disorder, therapy, therapist, or therapeutic relationship - that is, under naturalistic conditions, as much as they can be categorized and evaluated. While researchers cannot calibrate these experimental conditions in RCTs, they can control the proofing conditions by standardizing the evaluation scale and protocolizing its application (Brun, Roussillon \& Attigui, 2016; Thurin, 2017; Blanc, 2018). These qualitative methods allow for a variety of intra- and inter-case evaluation processes in real-life situations, focusing on the change processes in the light of certain clinical aspects then quantifiable. According to Daniel Fishmann's (2000), they prioritize the evaluation of real efficacy as 
opposed to potential efficacy, which is too abstractly decontextualized by the statistical operation.

More recently, at the international level, research has evaluated the efficacy of types of therapeutic alliances (Krupnick, Sotsky, Simmens et al., 1996), types of psychotherapists (Kim, Wampold \& Bolt, 2006), types of therapeutic contexts (Cella, Stahl, Reme \& Chalder, 2011), and more specifically in the domain of psychoanalysis, the efficacy of therapies based on the study of trust in objects (Stänicke, Strømme, Killingmo \& Gullestad, 2014) or structural changes (Leuzinger-Bohleber et al., 2019a). In France, change processes have been evaluated according to the type of pathology (Thurin et al., 2006), type of psychological functions - narrativity (Baruch, C et al., 2005; Zigante, Borghine \& Golse, 2009), transitional playing skills (Blanc, 2015), or processes of discursive elaboration (Suarez-Labat, 2014).

While these post-ECR methods have revived the question of evaluation by integrating the real therapeutic context into evaluation practices, they still fail to grasp and address what is clinically effective for patients (and thus what analysts assume to be most effective at the level of practices), namely the work of accurately identifying "unique operative representations" on a case-by-case basis in the trusting relationship in which one psychological life is transferentially expressed to another. Such therapeutic effectiveness - at its most extreme - is completely different for each patient.

In short, it seems important to us to note that the two dominant models (each in their own way) leave in a "black box" what should, from a practitioner's point of view, be evaluated and reintroduced into the debate: the unique workings, hic et nunc, of the effectiveness of analytical therapies. In this sense, should we not broaden the concept of "evaluation" so as to embrace a more inclusive methodological horizon?

\section{TOWARD AN INTEGRATIVE EXTENSION OF THE EVALUATION MODEL IN PSYCHOANALYSIS}

To take a new departure for evaluating the efficacy of psychoanalysis, it is necessary to identify the precise point at which therapeutic effectiveness occurs in treatment. How and where does psychoanalysis act? There has been much debate around this issue, but it is still not finished. We do not pretend to provide the final word on the subject, but simply to 
position ourselves in defense of a new integrative and stratified approach to evaluation, centered on the uniqueness of the case.

\section{Outline of an Epistemological Reflection on the Effectiveness of Psychoanalysis}

We would like to defend the hypothesis accepted by analysts that listening and interacting with the subject's unicity are a major resource in their work and its effects, but here we describe it from a new perspective. We would like to emphasize the dimension of non-equivalence, non-measurability, and non-comparability in each transference and countertransference encounter. The analyst's clinical decision makes possible the emergence and handling of "unique operative representations", in the therapeutic situation.

\section{The Method Turned Upside-Down: Psychoanalysis and the Inversion of Positions}

If one word should be used to describe the approach inaugurated by Freud, we would willingly situate it in a methodological inversion. To "old-fashioned psychotherapi[es]" (Freud 1918, p. 52) based on the application of a generic method (X or Y) to a specific patient, Freud opposes the therapeutic challenge of allowing an individual patient to decide on the implementation for him of an idiosyncratic methodological goal, in an open and bespoke setting.

Indeed, it is up to the patient to perform the "somnambulistic extension of memory" (Freud in Freud \& Breuer, 1895, p. 98) through verbal or bodily acts (general method), relative to the conditions created by the analyst and his approach: notably, a desire - to support the framework -, an ethic - the uniqueness of each case -, adjuvant methods - free association, psychodrama, games, and any ad hoc discovery -, skills, and a theoretical frame of reference. By enlarging his psychological contents (verbalized, or acted then verbalized), the patient can explore his psychological life in another way and share it with the therapist, who in turn has the latitude to identify many elements and then resubmit them to the patient.

Such a reflexive "return to sender" has a "psycho-analytical" effect, that is, it breaks ("lysis") up ("ana") or decomposes the functioning of psychological activity ("psyche"). This decomposition, if applicable (and the risk of such an approach should be weighed up, especially with patients of fragile organization), engenders a psychological recomposition through the sole synthetic faculty of the "ego," which takes place in the comforting environment of the psychoanalytic session. Yet this synthesis is never identical. What the patient recognizes about himself via the analyst is "novel". After speaking, acting, or playing, 
the patient can no longer be the same as before. The analysis of his experience shifts the patient away from himself and leads to transformative processes, with a possible spectra of therapeutic effects.

\section{The Issue of the Case at the Heart of the Controversy}

Through this reduced schema of the process, we may grasp what founds the very heart of the psychoanalytic approach: the uniqueness of each case. This does not exclude more typological approaches such as the psychopathological or theoretical approach. Put simply, the generalizing value of knowledge clinically diminishes its operational value. In terms of effectiveness and comparatively to the other psychotherapies, the "analytical contribution" occurs at the very level of analyst's interventions, interpretations, and discoveries as well as through the patient's own surprises.

In psychoanalysis - unlike in medicine (Pomata, 2013), traditional psychology (Danziger, 1990), or in more contemporary trends of symptom-focused therapies (Cottraux, 2017) - the general truth of a theory is not applied to specific cases. Instead, the verbalization approach is supported so that the subject (who is placed at the center) can speak the truth without contextual constraints (be they social or scientific) and then be accompanied in its emergence, thus bringing about effects.

In other words, for the analyst, each patient is considered to be unique, and patients know that they will not be received as a case of a specific psychological disorder but as universal singulars of speech. Such a therapeutic challenge is evidently lodged within the confines of the "all generic" approach (in medicine, the neurosciences, or other psychotherapy approaches). It is lodged there without purporting to abolish other perspectives, but instead proposes an alternative working vector according to the therapeutic indication.

Psychoanalysis, by placing the uniqueness of the case at the center, militates de facto for a greater consideration of its own effective procedures in the process of evaluating its effectiveness. Psychoanalytic effectiveness is indeed tested from the situated constructions of the analyst, elaborated by one analyst for one patient on a given therapeutic occasion. There are no generic keys. Effective knowledge is that which, case by case, initiates, accompanies, or accelerates the processes of psychological mobilization, reaction, transformation, or change linked to the singular psychological normativity of the subject. These take place "piecemeal to begin with" (Freud in Freud \& Breuer, 1895, p. 105), and never simultaneously as in the case of chemical treatment. Sometimes a single word will have greater effect than what is repeated 
session after session, thus rendering irrelevant any statistical approach. These processes can be inversed, become stuck, and then suddenly break through barriers, surging when least expected.

Since the turn of the 2000s, research on change processes has focused on "effectiveness" rather than "efficacy" in order to distinguish approaches implemented under naturalistic conditions from statistical approaches (Chambless \& Hollon, 1998). We would like here to give "effectiveness" a more precise psychoanalytical meaning. We propose to refer to "psychoanalytical effectiveness" to designate the accumulation of clinical effects obtained hic et nunc in virtue of the psychoanalyst's adapted interventions. Accounting for effectiveness in psychoanalysis can only occur in retrospect in the singular process of case writing. Yet how can we conciliate this singularity of psychoanalytic evaluation with the scientific and political demand for rigorous, typological, and quantified knowledge?

\section{Toward a Stratified Model Centered on the Case's Uniqueness?}

The sociology of quantification demonstrates that "measuring something" is a dual cognitive operation, which first requires the creation of a dimension of equivalence, and then the act of measuring (Desrosières, 2008). Phenomena are not measurable in themselves, but are so determined on the basis of conventions of quantification. The key issue among psychoanalysts is their clinical refusal to reduce, a priori, patients to types and numbers. We can, by contrast, accept the importance of translating, a posteriori, the effectiveness of the analytical work into different languages, both statistical (efficacy) and administrative (efficiency).

Let us now formulate our problem: what translation conventions can we accept to convey the uniqueness of cases in practice into types and numbers without making the clinical relevance of these evaluative chains disappear? More generally, this problem requires us to preserve the reference through successive chains of translation. In this respect, we acknowledge our double indebtedness to both the principles of grounded theory (Glaser \& Straus, 1967) and the thought of Latour (1993). Their epistemological propositions freely inspire our own with regard to this integrative model, whose principles we would like to set out here.

\section{Our Proposal}


The orientation will be as follows: after establishing the reference (day-to-day work with a patient), how can we successively translate all the phases of clinical thought? Focusing on the issue of evaluation: how can we translate analytical, evaluative operations from the collection of patient self-evaluations to the final evaluation, not to mention the primary and secondary evaluations of the treating analyst, follow-up evaluations, or even those of groups of independent researchers?

The attention accorded to the intermediary evaluation operations prompts us to consider a discontinuist and stratified model, the continuity of which must be underpinned by clinical meaningfulness. The five major strata could be the following:

- the selective collection of unique data: verbatim words of the patient and analyst; "ethnographical" sequences of observation; the patient's diverse productions where applicable (i.e., drawings, modeling clay);

- self-evaluations of what matters to the subject, as identified by the analyst based on his clinical attention and listening to what is specifically meaningful to the patient;

- primary evaluations of the analyst: hetero-evaluations of the unique's significativity, with transference and countertransference elements, interpretations of the material, constructions, extraction of case features, etc.;

- secondary evaluations of the analyst: hetero-evaluations of the typical's significativity, with metapsychological, psychopathological, and etiological elements;

- tertiary evaluations of the analyst in retrospect: hetero-evaluations of the quantifiable's significativity, with the quantification of therapeutic elements for comparative purposes and the quantification of the patient's final satisfaction, if applicable.

For strata 1 and 2, research work can be enriched and crossed by means of additional strata (of the same level) resulting from the independent work of follow-up analysts (questionnaires, interviews). For strata 3, 4, and 5, this work can be made dialectal by additional strata (of the same level), consisting of external evaluations of the same case based on new raw data that are gathered by research analysts and collectively interpreted by independent working groups.

\section{What is Known and What is New}

We are not attempting to reinvent what largely exists. The principle of a written stratification - for example, distinguishing the patient's verbatim, the summary of certain 
sequences, and the interpretations and constructions of the analyst - has been practiced since the time of Freud in his case studies. The idea of adding strata corresponding to the external evaluations appeared in the post-war period with Schjelderup. In his study of the therapeutic effectiveness of psychoanalysis ( 28 cases treated by him), he proposed to integrate a stratum based on "questionnaires" - later sent to the patient- and a stratum based on "interviews" conducted by an external doctor or person (Schjelderup, 1955). The idea of integrating a more comprehensive verbatim stratum with respect to external evaluations can be found in Pfeffer's famous study, which also adds the stratum of a collective discussion among the treating analyst, follow-up analyst, and independent research analysts (Pfeffer, 1961). The idea of stratifying the written material in this manner was then adopted in all subsequent research groups on the effectiveness of psychoanalysis (Schlessinger \& Robbins, 1974; Oremland, Blacker \& Norman, 1975; Wallerstein, 1968, 1986; Kantrowitz, Katz \& Paolitto, 1990a, 1990b, 1990c).

As data recording and processing techniques progressed, the raw data stratum became more complex with the inclusion of video and artificial intelligence analysis strata (Dahl, Kächele \& Thomä, 1988). Other complexities have been added since the 2000s. The idea of multiplying the levels of data analysis according to different specialized methods is implemented with the Amalia X case of the Ulm Psychoanalytic Process Research Study Group (Kächele et al., 2006). A few case studies incorporate a stratum based on the reinjection of the results obtained in previous evaluation work (drawn from follow-up interviews) in order to test them (Stänicke, Strømme, Killingmo \& Gullestad, 2014). Today, studies are carried out at several levels and in several successive waves, involving a plurality of cases treated according to different approaches (not only psychoanalytical), with emphasis placed on one aspect of the processes such as "structural changes" (Leuzinger-Bohleber et al., 2019a).

So if the staged integration of heterogeneous evaluative levels currently exists in psychoanalytic writing (Chiesa, 2005), what does our model offer? The answer is twofold.

First, it includes an essential stratum that has hitherto been poorly visible, namely a reflexive dimension on the unique elements that come into play for a patient: the crucial value of speech in his personal history; his unconscious investment in representations with idiosyncratic meanings; and his own special psychic associativity. These contingent elements, even if they cannot be reproduced, are examples of what needs to be evaluated in respect to their relative transformations to better appreciate the effectiveness of psychoanalysis. They lie 
at the very operative heart of the changes and make it possible to not be cut off from the foundation of practice.

Second, in our opinion, the idea of developing a model based on what already exists seems to clarify the epistemological position of psychoanalysis among the sciences and its methodological position in the field of research on the evaluation of the psychotherapies. By visualizing this model, we can better understand that psychoanalysis is clearly not on the side of the experimental sciences - transcribed in IMRAD format (Introduction, Methods, Results and Discussion). Such a discipline is indeed situated among the humanities and social sciences (as a specific clinical one). It is thus important to be able to show that its research can meet the requirement of an intersubjective control of interpretations. As each stratum is differentiated, criticism may occur during each stage of the clinician evaluation: a clinical researcher from outside the study may thus discover new self-evaluations of the patient in the verbatim material or reorder the significance of the analyst's propositions in this regard. Similarly, the reader has the freedom to conceive other possible constructions, make other psychopathological or theoretical propositions, or identify other quantifiable items. He can discuss the very nature of the quantifiable evaluation items (e.g., for whatever reason, he may choose to negate the "verbalization of emotions" in favor of the "evolution of defense mechanisms") and even deliberate over the quantified evaluation of these items with regard to the preceding strata (e.g., refusing in one particular case that a patient moved from a difficult to fluid "internal narrative," or from $2 / 10$ to $9 / 10$ on a chosen scale).

By focusing on the uniqueness of the case and supporting actual psychoanalytic work, researchers can thus return to what clinically founds all the later chains. Considering the "easing of the splitting mechanism" at the end of the chain, for example, this is ultimately in reference to the accessible portions of the clinical material, similarly to the logic of arborescence in grounded theory (Glaser \& Strauss, 1967). Therefore, with this model which preserves the autonomy of each stratum, sanctifies the level of uniqueness, and ensures the continuity of clinical meaningfulness despite the heterogeneity of levels - we give ourselves the means to argue in favor of the rigor of our own evaluative thinking.

Last but not least, such a model allows policy-makers not to be tied to abstract numerical tables, diagrams, and charts - which are all too often only pure "forms" that mimic scientific relevance. They can instead grasp the meaning - unique on each occasion, although this uniqueness can be connected in series - of the quantified conclusions addressed to them. Likewise, care policies are not cut off from what works case by case. And even if policy- 
makers do not take the trouble to go and see the work for themselves, there is a bond of trust: they are assured that the clinical basis of quantified evaluations can be verified (these are not senseless numbers as described by Bachelard and cited in the article's epigraph). Finally, the researcher, in his legitimate critical concern, is not kept apart either by an undifferentiated narrative that blends material, interpretation and theory (classical cases of the analytical tradition) or by statistics, whose clinical value is weakened by epistemic bias (case of RCTs or standardized scales).

\section{CONCLUSION}

We hope that this article was able to demonstrate the ethical, clinical, and epistemic necessity of defending a balanced research model in psychoanalysis, by neither sacrificing "good clinical practice" on the altar of "good science" or "good management" nor forgoing the demands of the socius in the name of extraterritoriality with irresponsible consequences. For this reason, we propose a stratified model, where the bottom-up (from the uniqueness of the single case to the typical and then quantified case) and top-down movements (from institutional requirements to real-life practices) may converge and coexist at the level of intermediate schemes.

This requires us to consider anew the scientific question of evaluation by de-identifying it from the most commonly used standard methods (RCTs, evaluation scales) and redeploying it on the side of the humanities and social sciences - while taking into account the specificities of the clinical setting and, more precisely, the psychoanalytical clinic.

Implemented in its most complex forms - including the fundamental strata of the uniqueness of the case - this model would make it possible to raise even more the datastructuring standards in the analytical field and thus enhance the content of clinical discussions. In addition, in the long term, it would also allow much finer inter-case comparisons within the same clinical orientation (research requirement) or between different orientations (science and healthcare system requirements) by refocusing on the uniqueness of the case and the actual conditions of therapeutic work.

In the longer term, such a reflexive model - through the renewed attention given to the intermediate processes that stand at the height of practice - might even influence analytical work itself: ethical positioning, clinical attention, the rigor of the psychoanalyst's conceptions, and his or her confrontations/debates with peers. 


\section{REFERENCES}

Abbass, A., Hancock, J., Henderson, J., \& Kisely, S. (2006). Short-term psychodynamic psychotherapies for common mental disorders. In Cochrane Database of Systematic Reviews, issue 4, article $n^{\circ}$ CD004687.

Abbass, A., Kisely, S., \& KroenKe, K. (2009). Short-term psychodynamic psychotherapy for somatic disorders: Systematic review and meta-analysis of clinical trials. In Psychotherapy and Psychosomatics, $\mathrm{n}^{\circ}$ 78, pp. 265-274.

Bachelard, G. (1938/2002). The Formation of the Scientific Mind. Manchester: Clinamen Press.

Baruch, C., Gibeault, A., \& LoukomskaÏA, M. (2005). Évaluation de psychothérapies psychanalytiques: Une étude pilote. In Cliniques méditerranéennes, ${ }^{\circ}$ 71, pp. 259-267.

BenAmouzig, D. (2005). La santé au miroir de l'économie. Une histoire de l'économie de la santé en France. Paris: PUF.

Benish, S., Imel, Z., \& Wampold, B. (2008). The relative efficacy of bona fide psychotherapies for treating post-traumatic stress disorder: A meta-analysis of direct comparisons. In Clinical Psychology Review, ${ }^{\circ}$ 28/5, pp. 746-758.

BerG, M., \& Timmermans, S. (2003). The gold standard: The challenge of evidencebased medicine and standardization in health. Philadelphia, PA: Temple University Press.

Blanc, A. (2015). Psychodrame psychanalytique et jeu transitionnel. Évaluation du processus thérapeutique et des effets associés auprès d'enfants en âge de latence et d'adolescents suivis en centre-médico-psychologique. $\mathrm{PhD}$ dissertation, Paris.

Blanc, A. (2018). Evaluation, psychothérapies et psychanalyse: réflexions et perspectives éthiques, épistémologiques et scientifiques. In In Analysis, n 2/2, pp. 163-170.

Boltanski, L., \& Chiapello, E. (1999). Le nouvel esprit du capitalisme. Paris: Gallimard.

BuCCI, W. (1997). Psychoanalysis and Cognitive Science: A multiple Code Theory. New York: Guilford Press.

CARey, T. \& STILES, W. (2015). Some problems with randomized controlled trials and some viable alternatives. In Clinical Psychology \& Psychotherapy, ${ }^{\circ} 23 / 1$, pp. 87-95. 
Brun, A., Roussillon, R., \& AtTigui, P. (2016). Évaluation clinique des psychothérapies psychanalytiques. Dispositifs individuels, groupaux et institutionnels. Paris: Dunod.

ChIESA, M. (2005). Can psychoanalytic research integrate and improve knowledge for clinical practice? In The Scandinavian Psychoanalytic Review, ${ }^{\circ}$ 28/1, pp. 31-39.

Cella, M., Stahl, M., Endresen, R. \& Chalder, T. (2011). Therapist effects in routine psychotherapy practice: An account from chronic fatigue syndrome. In Psychotherapy Research, $\mathrm{n}^{\circ} 21$, pp. 168-178.

Chambless, D., \& Hollon, D. (1998). Defining empirically supported therapies. In Journal of Consulting and Clinical Psychology, $\mathrm{n}^{\circ}$ 66/1, pp. 7-18.

Champion, F. (2008). Psychothérapie et société. Paris: Armand Colin.

CoRiAT, I. (1917). Some statistical results of the psychoanalytical treatment of the psychoneuroses. In Psychoanalytic Review, n 4, pp. 209-216.

CotTRAuX, J. (2017). Les psychothérapies cognitives et comportementales. Issy-lesMoulineaux: Elsevier Masson.

CRITS-Cristoph, P., \& BARBER, J. (2000). Long-term psychotherapy. In SNYDER, R., \& IngRAM, R. (2000). Handbook of Psychological Change: Psychotherapy Processes \& Practices for the Twenty-First Century. New York: Wiley, pp. 455-473.

Dahl, H., Kächele, H., \& ThOMÄ, H. (1988). Psychoanalytic Process Research Strategies. Berlin/Heidelberg/NewYork/London/Paris/Tokyo: Springer-Verlag.

DAhl, H., \& TelleR, V. (1994). The characteristics, identification, and applications of frames, In Psychotherapy Research, vol. 4/3-4, pp. 253-276.

DANZiger, K. (1990). Constructing the Subject: Historical Origins of Psychological Research. Cambridge, UK: Cambridge University Press.

DeLeOn, P. (1988). Public policy and public service. In American Psychologist, $\mathrm{n}^{\circ} 43$, pp. 309-315.

De MaAt, S., De Jonghe, F., Schoevers, R., \& DekKer, J. (2009). The effectiveness of long-term psychoanalytic therapy: A systematic review of empirical studies. In Harvard review of psychiatry, $\mathrm{n}^{\circ} 17 / 1, \mathrm{pp} .1-23$.

DesRosiERES, A. (2008). Pour une sociologie historique de la quantification. L'argument statistique I. Paris: Presses de l'Ecole des mines.

DOURY, M. (1997). Le débat immobile. L'argumentation dans le débat médiatique sur les parasciences. Paris: Kimé. 
Elkin, I., Gibbons, R., Shea, T. \& Shaw, B. (1996). Science is not a trial (but it can sometimes be a tribulation). In Journal of Consulting and Clinical Psychology, ${ }^{\circ}$ 64, pp. 92103.

FischmAn, G., et al. (2009). L'évaluation de la psychothérapie et de la psychanalyse. Fondements et enjeux. Paris: Masson.

FISHMAN, D. (1999). The case for pragmatic psychology. New York, NY: New York University Press.

FishMAN, D. (2000). Transcending the efficacy versus effectiveness research debate: Proposal for a new electronic "Journal of Pragmatic Case Studies". In Prevention and Treatment 3, art. 8.

FonAGy, P. (2015). The effectiveness of psychodynamic psychotherapies: An update. In World Psychiatry, ${ }^{\circ}$ 14/2, 2015, pp. 137-50.

Freud, S \& Breuer, J. (1895). Studies on Hysteria. In Standard Edition, n 2, pp. 1335 .

Freud, S. (1909[1908]). Analysis of a Phobia In a Five-Year-Old Boy, In Standard Edition, $\mathrm{n}^{\circ} 10$, pp. 3-149.

FreUd, S. (1909). Notes upon a Case of Obsessional Neurosis. In Standard Edition, $\mathrm{n}^{\circ}$ 10, pp. 153-249.

FrEUD, S. (1918[1914]). From the history of on infantile Neurosis. In Standard Edition, $\mathrm{n}^{\circ} 17$, pp. 1-124.

GARFIELD S. (1992). Major issues in psychotherapy research. In FrEEDHEIM, D. (1992). History of Psychotherapy. A Century of Change. Washington: American Psychological Association, pp. 335-359.

Ginzburg, C. (1989). Clues: Roots of an Evidential Paradigm. In C. Ginzburg, Clues, Myths and the Historical Method. Baltimore: Johns Hopkins University Press, pp. 96-125.

GlaSER, B., \& Strauss, A. (1967/2010). La découverte de la théorie ancrée: Stratégies pour la recherche qualitative. Paris: Armand Colin.

Grünbaum, A. (1984). The Foundations of Psychoanalysis: A Philosophical Critique. Berkeley, CA: University of California Press.

GRÜNBAUM, A. (1988). The role of the case study method in the foundations of psychoanalysis. In Canadian Journal of Philosophy, vol. 19, pp. 623-658.

HAAGA, D., \& STILES, W. (2000). Randomized clinical trials in psychotherapy research: Methodology, design, and evaluation. In SNYDER, C., \& INGRAM, R. (2000). Handbook of 
Psychological Change: Psychotherapy Processes \& Practices for the Twenty-first Century. New York: Wiley, pp. 14-39.

Haliday H., \& Naudin D. (2019). Comment qualifier l'impact des réformes de santé sur la qualité de vie au travail des soignants? Leçons de l'implémentation de la tarification à l'activité et de l'informatisation des services de soins dans les hôpitaux français. In Ethique et santé, $\mathrm{n}^{\circ} 16 / 2$, pp. 51-58.

Horwitz, L., Gabbard, G., Allen, J., Frieswyk, S., Colson, D., Newsom, G., et al. (1996). Borderline personality disorder: Tailoring the therapy to the patient. Washington (DC): American Psychiatric Press.

JONES, E. (1985). Manual for the psychotherapy process $Q$-sort. Unpublished manuscript. University of California: Berkeley.

KÄCHELE, H. (1988). Clinical and scientific aspects of the Ulm process model of psychoanalysis. In International Journal of Psycho-Analysis, $\mathrm{n}^{\circ}$ 69, 1988, pp. 65-73.

KäChele, H., LeVy, R., \& ABLON, S. (2012). Psychodynamic psychotherapy research: evidence-based practice and practice-based evidence. New York: Humana Press.

Kächele, H., Albani, C., Buchheim, A., Hölzer, M., Hohage, R., Mergenthaler, E., Pablo Jimenez, J., Leuzinger-Bohleber, M., Neudert-Dreyer, L., Pokorny, D., \& Тномё, H. (2006). The german specimen case, Amalia X: Empirical studies. In The International Journal of Psycho-Analysis, $\mathrm{n}^{\circ}$ 87, pp. 809-826.

Kantrowitz J., Katz A., \& PaOlitto F. (1990a). Follow up of psychoanalysis five to ten years after termination: I. Stability of change. In Journal of the American Psycho-Analytic Association, vol. 38, pp. 471-496.

Kantrowitz J., Katz A., \& PaOlitto F. (1990b). Follow up of psychoanalysis five to ten years after termination: II. Development of the Self-analytic function. In Journal of the American Psycho-Analytic Association, vol. 38, pp. 637-654.

Kantrowitz J., Katz A., \& PAOLitTo F. (1990c). Follow up of psychoanalysis five to ten years after termination: III. The relation between the resolution of the transference and the patient-analyst match. In Journal of the American Psycho-Analytic Association, vol. 38, pp. 655-678.

KAZDIN, A. (1997). A model for developing effective treatments: Progression and interplay of theory, research, and practice. In Journal of Clinical Child Psychiatry, $\mathrm{n}^{\circ}$ 26/2, pp. 114-129. 
KAZDIN, A. (2001). Progression of therapy research and clinical application of treatment require better understanding of the change process. In Clinical Psychology: Science and Practice, n $^{\circ} 8 / 2$, pp. 143-151.

KAZDIN A. (2014). Research Design in Clinical Psychology. Harlow: Pearson.

Keefe, J., McCarthy, K., Dinger, U., Zilcha-Mano, S., \& Barber, J. (2014). A meta-analytic review of psychodynamic therapies for anxiety disorders. In Clinical Psychology Review, $\mathrm{n}^{\circ}$ 34/4, pp. 309-323.

KIM, D.-G., WAMPOLD, B., \& Bolt, D. (2006). Therapist effects in psychotherapy: A random-effects modelling of the National Institute of Mental Health Treatment of Depression Collaborative Research Program data. Psychotherapy Research, $\mathrm{n}^{\circ}$ 16, pp. 182-187.

Kivlighan, D., Goldberg, S., Abbas, M., Pace, B., Yulish, N., Thomas, J., \& WAMPOLD, B. (2015). The enduring effects of psychodynamic treatments vis-à-vis alternative treatments: A multilevel longitudinal meta-analysis. In Clinical Psychology Review, ${ }^{\circ}$ 40, pp. $1-14$.

KLERMAN, G. (1983). The efficacy of psychotherapy as the basis for public policy. In American Psychologist, $\mathrm{n}^{\circ}$ 38, pp. 929-934.

Krupnick, J., Sotski, S., Simmens, S., Elkin, I., \& Moyer. J. (1996). The role of the therapeutic alliance in psychotherapy and pharmacotherapy outcome: Findings in the National Institute of Mental Health Treatment of Depression Collaborative Research Program. In Journal of Consulting and Clinical Psychology, $n^{\circ}$ 64, pp. 532-539.

LACAN, J. (1975). Intervention de Jacques Lacan. Séance du vendredi 2 novembre. In Lettres de l'École freudienne, $\mathrm{n}^{\circ} 15$, pp. 79-80.

LAtour, B. (1993). Le topofil de Boa Vista ou la référence scientifique. Montage photophilosophique. In Raison Pratique, ${ }^{\circ}$ 4, pp. 187-216.

Lascoumes, P., \& Le Gales, P. (2004). Gouverner par les instruments. Paris: Presses de Sciences Po.

Lazar S. \& Yeoman, F. (2014). Guest editors' introduction. In Psychodynamic Psychiatry, vol. 42, pp. 347-352.

LEICHSENRING, F., \& RABUNG, S. (2008). Effectiveness of long-term psychodynamic psychotherapy: A meta-analysis. Journal of the American Medical Association, $\mathrm{n}^{\circ}$ 300/13, p. 1551-1565. 
LEICHSENRING, F., \& RABUNG, S. (2011). Long-term psychodynamic psychotherapy in complex mental disorders: Update of a meta-analysis. In The British Journal of Psychiatry, $\mathrm{n}^{\circ}$ 199/1, pp. 15-22.

LEICHSENRING, F., \& LEIBING, E. (2003). The effectiveness of psychodynamic therapy and cognitive behavioral therapy in the treatment of personality disorders: A meta- analysis. In American Journal of Psychiatry, $\mathrm{n}^{\circ}$ 160, pp. 1223-1232.

Leuzinger-Bohleber, M., Kächele, H. et al. (2015). An Open Door Review of Outcome and Process Studies in Psychoanalysis. Third Edition. Londres: International Psychoanalytical Association.

LeuZinger-Bohleber, M., \& TARget, M. (2002). Outcomes of psychoanalytic treatment: Perspectives for therapists and researchers. Philadelphia, PA: Whurr Publishers.

Leuzinger-Bohleber, M., Kaufhold, J., Kallenbach, L., Negele, A., ERnst, M., Keller, W., Fiedler, G, Hautzinger, M., Bahrke, U., \& Beutel, M. (2019a). How to measure sustained psychic transformations in long-term treatments of chronically depressed patients: Symptomatic and structural changes in the LAC Depression Study of the outcome of cognitive-behavioural and psychoanalytic long-term treatments. In The International Journal of Psycho-Analysis, $\mathrm{n}^{\circ}$ 100/1, pp. 99-127.

Leuzinger-Bohleber, M., Hautzinger, M., Fiedler, G., Keller, W., Bahrke, U, Kallenbach, L., Kaufhold, J., Ernst, M., Negele, A., Schoett, M., Küchenhoff, H., Günther, F., Rüger, B., \& Beutel, M. (2019b). Outcome of psychoanalytic and cognitive-behavioural long-term therapy with chronically depressed patients: A controlled trial with preferential and randomized allocation. In The Canadian Journal of Psychiatry / La Revue Canadienne de Psychiatrie, $\mathrm{n}^{\circ}$ 64/1, pp. 47-58.

LIPSEY, M., \& WILSON, B. (1993). The efficacy of psychological, educational, and behavioral treatment: Confirmation from meta-analysis. In American Psychologist, $\mathrm{n}^{\circ}$ 48, p.. 1181-1209.

Luborsky, L., Singer, B., \& LubORSKy, L. (1975). Comparative studies of psychotherapies: Is it true that everyone has won and all must have prizes? In Archives of General Psychiatry, n 32, pp. 995-1008.

LubORSKY, L. \& Crits-Christoph, P. (1990). Understanding Transference. New York: Basic Books.

MARKs, H. (1999). La médecine des preuves. Histoire et anthropologie des essais cliniques (1900-1990). Paris: Les Empêcheurs de penser en rond. 
Melander, H., Ahlqvist-Rastad, J., Meijer, G., \& Beerman, B. (2003). Evidence b(i)ased medicine - selective reporting from studies sponsored by pharmaceutical industry: Review of studies in new drug applications. In British Medical Journal, $\mathrm{n}^{\circ}$ 326, pp. 11711176.

Mellor-Clark, J., Cross, S., Macdonald, J., \& SkJulsvik, T. (2014). Leading horses to water: Lessons from a decade of helping psychological therapy services use routine outcome measurement to improve practice. In Administration and Policy in Mental Health and Mental Health Services Research, n ${ }^{\circ} 43 / 3$, pp. 279-285.

Newman, F., \& Howard, K. (1986). Therapeutic effort, treatment outcome, and national health policy. In American Psychologist, $\mathrm{n}^{\circ}$ 41, pp. 181-187.

Norcross, J., Beutler, L., \& LeVANT, R., 2005. Evidence based practices in mental health: Debate and dialogue on the fundamental questions. Washington, DC: American Psychological Association.

Oremland, J., Blacker, K., \& Norman, H. (1975). Incompleteness in "Successful" Psychoanalyses: A follow-up study. In Journal of the American Psychoanalytic Association, $n^{\circ} 23 / 4$, pp. $819-844$.

PAUL, G. (1967). Strategy of outcome research in psychotherapy. In Journal of Counseling Psychology, ${ }^{\circ}$ 31/2, pp. 109-118.

Pestre, D. (2010). Introduction aux science studies. Paris: La Découverte.

PFEFFER, A. (1959). A procedure for evaluating the results of psychoanalysis: A preliminary report. In Journal of the American Psychoanalytic Association, ${ }^{\circ}$ 7, pp. 418-444.

PFEFFER, A. (1961). Follow-up study of a satisfactory analysis. In Journal of the American Psychoanalytic Association, n 9, pp. 698-718.

PfEFFER, A. (1963). The meaning of the analyst after analysis. In Journal of the American Psychoanalytic Association, $\mathrm{n}^{\circ} 11$, pp. 229-244.

Pomata, G. (2013). The recipe and the case: Epistemic genres and the dynamics of cognitive practices. In K. von Greyerz, S. Flubacher, \& P. Senn, Wissenschaftsgeschichte und Geschichte des Wissens im Dialog. Connecting Science and Knowledge. Göttingen: V\&R Unipress, pp. 131-154.

SCHJELDERUP, H. (1955). Lasting effects of psychoanalytic treatment. In Psychiatry, vol. 18/2, pp. 109-133.

SCHJELDERUP, H. (1956). Personality-changing processes of psychoanalytic treatment. In Nordisk Psykologi, vol. 8/1-2, pp. 47-64. 
SCHLESSinger, N., \& RobBins, F. (1974). Assessment and follow-up in psychoanalysis. In Journal of the American Psychoanalytic Association, n 22, pp. 542-567.

Seshia S. \& Young, G. (2013). The evidence-based medicine paradigm: Where are we 20 years later? Part 1. In Canadian Journal of Neurological Sciences, $n^{\circ} 40$, pp. 465-474

Seshia S. \& Young, G. (2013). The evidence-based medicine paradigm: Where are we 20 years later? Part 2. In Canadian Journal of Neurological Sciences, $n^{\circ} 40$, pp. 475-481.

Smith, M., Glass, G., \& Miller, T. (1980). The benefits of psychotherapy. Baltimore: Johns Hopkins University Press.

SPEER, D. (1994). Can treatment research inform decision makers? Nonexperimental method issues and examples among older outpatients. In Journal of Consulting and Clinical Psychology, $\mathrm{n}^{\circ}$ 62, pp. 560-568.

Steinert, C., Munder, T., Rabung, S., Hoyer, J., \& Leichsenring, F. (2017). Psychodynamic therapy: as efficacious as other empirically supported treatments? A metaanalysis testing equivalence of outcomes. In American Journal of Psychiatry, $\mathrm{n}^{\circ}$ 174/10, pp. 943-953.

STRUPP, H. (1986). Psychotherapy: Research, practice, and public policy (How to avoid dead ends). In American Psychologist, $\mathrm{n}^{\circ}$ 41, pp. 120-130.

SuAREZ-LABAT, H. (2014). Les investigations projectives et cognitives: Des éclairages pluriels sur les états autistiques et leurs destins. In Amy, M.-D., 2014. Autismes et psychanalyses. Évolution des pratiques, recherches et articulations. Paris: Erès, pp. 321-346.

THuRIN, J.-M. (2017). De l'évaluation des psychothérapies à la recherche en psychothérapie et en psychanalyse. In Research in Psychoanalysis 23:55a-68a.

Thurin, M., Lapeyronnie-Robine, B., \& Thurin, J.-M. (2006). Mise en place et premiers résultats d'une recherche naturaliste en réseau répondant aux critères actuels de qualité méthodologique. In Bulletin de Psychologie 486:591-603.

Thurin, J-M. \& THURIN M. (2007). Évaluer les psychothérapies: méthodes et pratiques, Paris: Dunod.

TOURNAY, V., et al. (2007). La gouvernance des innovations médicales. Paris: PUF.

Town, J., Diener, M., Abbass, A., Leichsenring, F., Driessen, E., \& Rabung, S. (2012). A meta-analysis of psychodynamic psychotherapy outcomes: Evaluating the effects of research-specific procedures. In Psychotherapy, n 49/3, pp. 276-290.

VISENTINI, G. (2017). La scientificité ouverte. «Controverses poppériennes » sur la méthode. In In analysis, $\mathrm{n}^{\circ}$ 2, pp. 82-89. 
Visentini, G. (2015). Pourquoi la psychanalyse est une science. Freud épistémologue. Paris: PUF.

WallersteIn, R. (1986). Forty-two Lives in Treatment. New York: Guilford Press.

WALlersteIn, R. (1991). Proposal to the Ludwig Foundation for a Collaborative MultiSite Program of Psychoanalytic Therapy Research. Unpublished Report.

WALLERSTEIN, R. (2001). The generations of psychotherapy research. An overview. In Psychoanalytic Psychology, vol. 18/2, pp. 243-267.

WALlERSTEIN, R. (1968). The psychotherapy research project of the Menninger Foundation: A semi-final view. In SCHLIEN, J., 1968. Research in Psychotherapy. Washington, DC: American Psychological Association, vol. 3., pp. 584-605.

WAMPOLD, B., \& IMEL, Z. (2015). The great psychotherapy debate: The evidence for what makes psychotherapy work. New York: Routledge/Taylor \& Francis Group.

Wampold, B., Minami, T., Tierney, S., Baskin, T., \& Bhati K. (2002). A meta(re)analysis of the effects of cognitive therapy versus "other therapies" for depression. In Journal of Affective Disorders, $\mathrm{n}^{\circ}$ 68, pp. 159-165.

WEISS, J. (1986). Theory and clinical observations. In WEISS, J., \& SAMPSON, H. (1986). The Psychoanalytic Process: Theory, Clinical Observation, and Empirical Research. New York: Guilford Press, pp. 3-138.

ZEPF, S. (2008). Naturalistic studies of psychoanalytic treatments: some epistemological and methodological remarks. In The Scandinavian Psychoanalytic Review, n ${ }^{\circ} 31 / 1$, pp. 50-60.

Zigante, F. Borghine, A., \& Golse, B. (2009). Narrativité des enfants en psychothérapie analytique: évaluation du changement. In La psychiatrie de l'enfant, $\mathrm{n}^{\circ}$ 52, $\mathrm{p}$.. 5-43. 